\title{
ANTIGENIC ANALYSIS AND BIOCHEMICAL CHARACTERS OF STRAINS OF ESCHERICHIA COLI, COMMONLY ASSOCIATED WITH HUMAN DIARRHOEA, ISOLATED FROM SPORADIC CASES OF GASTRO-ENTERITIS IN LOCAL POPULATION OF DOMESTIC ANIMALS ${ }^{1}$
}

\author{
J.N.S. YADAVA AND B.M. GUPTA \\ Central Drug Research Institute, Lucknow, India
}

(Received November 21, 1968)

\begin{abstract}
One hundred and fifty-three strains of Escherichia coli were isolated from sporadic cases of gastroenteritis from cows, calves, buffaloes, buffalocalves, goats, and kids. Thirty-six biochemical tests were conducted. On the basis of fermentation reaction of six selected sugars (rhamnose, sucrose, dulcitol, raffinose, salicin, and starch), 153 strains were classified into 28 biotypes. Biotypes I, V, VI, XI, XVIII, and XX appeared more common than the others. These six biotypes accounted for over $60 \%$ of the total (153) strains isolated from diarrhoea, dysentery, or white scours. Biotype XX predominated in buffaloes and buffalocalves, and Type VI in cows and calves, and in goats and kids. Again Type VI predominated in diarrhoea and dysentery and Type XI in white scour. Only 137 strains could be identified serologically. Sixty-five strains belonged to 7 human enteropathogenic ' $O$ ' groups (O26: B6, O55 : B5, O86 : B7, O112: B11, O119: B14, O125: B15, and O126: B16). Group $\mathrm{O} 26$ predominated in goats and kids, $\mathrm{O} 125$ in buffaloes and buffalocalves, and $\mathrm{O} 119$ in cows and calves. Another 72 strains belonged to 31 ' $\mathrm{O}$ ' groups, which are not known to be associated with infantile diarrhoea and gastroenteritis of human. Serological heterogenicity was observed within a single biotype and, similarly, strains within a single serotype differed in their biochemical characters.
\end{abstract}

Bacteriological study of animal gastroenteritis provides opportunity for direct enumeration and identification in animal intestine of forms and types of Escherichia coli flora that are known to be commonly associated with human diarrhoea (1-6). Identification and knowledge of ' $O$ ' and $\mathrm{H}$ antigens of the strains $(5-7)$ enable us to speculate or trace human or extra-human source $(5,8)$ of new outbreaks of animal gastroenteritis $(9-13)$, and furthers our understanding and knowledge of the spread of diseases common to man and domestic animals. Differences in biochemical characters in strains may

1 Communication No. 1324 from Central Drug Research Institute, Lucknow. 
reveal existence of novel biotypes $(1,14-18)$ and their possible association with certain serotypes $(11,19)$ or with animal species $(7)$, their age $(20)$, and type of the disease $(11,21-25)$, or even their duration (26). It has been suggested that differences in biochemical character of strains in a serotype may arise because of the different origin of serologically identical strains (17).

In the present paper, results of some of the above studies with 153 strains of Escherichia coli isolated from faecal samples of sporadic cases of gastroenteritis of domestic animals in Lucknow are presented.

\section{MATERIALS AND METHODS}

Isolation and culture. Faecal samples of hospitalised untreated domestic animals of the Lucknow Municipal area were collected from Veterinary Hospitals, Badshahbagh and Havelock Road, Lucknow. The external anal area of the animal was cleansed with cotton moistened with lysol $(0.01 \% \mathrm{v} / \mathrm{v})$. Sterile cotton swab attached to an 8-inlong wire was moistened with sterile $1.0 \%(\mathrm{w} / \mathrm{v})$ peptone water and introduced gently into the rectum and twisted inside so as to touch the mucosa. The swab was pulled out and transferred to a sterile test tube. It was brought immediately to the laboratory and suspended in $2 \mathrm{ml}$ of sterile nutrient broth (peptone, $20 \mathrm{~g}$; NaCl, $5 \mathrm{~g}$; dextrose, $2 \mathrm{~g}$; disodium hydrogen phosphate, $2.5 \mathrm{~g}$; distilled water to 1 liter and stirred thoroughly. A loopful of the broth was streaked on MacConkey agar plate and incubated aerobically at $37^{\circ}$ for $18 \mathrm{hr}$ for the appearance of lactose-fermenting pink colonies. A colony when found was resuspended in nutrient broth and streaked on MacConkey agar once again. Culture from a well isolated colony was made on nutrient agar (20 g Difco agar/liter nutrient broth) slant and subcultured every 15 days. Isolates positive to indole (I) and Methyl Red (M) and negative to Voges-Proskauer (Vi) and citrate (C) were considered as E. coli.

Biochemical reactions. IMViC reactions, nitrate reduction, gelatin liquefaction, deamination of phenylalanine to phenyl pyruvic acid, organic acid utilization, and carbohydrate fermentation tests were done according to EDWARDS and EWING (27), catalase production according to CRUICKSHANK (28), hydrogen sulphide production according to CLARKE (29), urease activity according to CHRISTENSEN (30), decarboxylase test according to FALKOW (31), and growth in KCN medium according to EDWA RDS and FIFE (32).

Motility was determined by a hanging drop preparation and by stab culture (28). After addition of $5 \mathrm{ml}$ of $1 \%(\mathrm{w} / \mathrm{v})$ 2,3,5-triphenyltetrazolium chloride, to 1 liter of $0.7 \%$ nutrient agar the tubed media were stab inoculated and incubated overnight. Motile organisms showed a red diffused zone of growth spreading from the line of inoculation. Non-motile strains showed only red colour along the line of inoculation.

Serological typing. Serological typing of the strains of E. coli was done 
at the National Salmonella and Escherichia Centre, Central Research Institute, Kasauli. The following adsorbed $\mathrm{O}$ and $\mathrm{OB}$ antisera were used to determine the $\mathrm{O}$ and $\mathrm{K}(\mathrm{B})$ antigens.

$O B$ antisera. $\mathrm{O} 18: \mathrm{B} 21, \mathrm{O} 26: \mathrm{B} 6, \mathrm{O} 44: \mathrm{K} 74(\mathrm{~L}), \mathrm{O} 55: \mathrm{B} 5, \mathrm{O} 86: \mathrm{B} 7, \mathrm{O} 111$ : B4, O112:B11, O119:B14, O124:B17, O125:B15, O126:B16, O127:B8 and $\mathrm{O} 128: \mathrm{B} 12$.

O antisera. O18, O26, O44, O55, O86, O102, O111, O112, O119, O124, O125, O126, O127 and O128.

For the typing of the strains, slide and tube agglutination tests advocated by EDWARDS and EWING (27) were adopted. Strains that could not be typed at the National Centre (Kasauli) against these sera were sent to the International Escherichia Centre, Statens Serum Institute, Copenhagen. All the strains studied in this work have been deposited at Kasauli.

\section{RESULTS}

The source of 153 strains of $E$. coli used in this work is given in Table 1. All the strains were found to be similar in MR, VP, citrate, nitrate, ammonia, catalase, $\mathrm{H}_{2} \mathrm{~S}$, urease, gelatin, phenylalanine, and $\mathrm{KCN}$ reactions.

Table 1. Source of E. coli strains.

\begin{tabular}{c|c|c|c|c}
\hline Source & $\begin{array}{c}\text { No. of } \\
\text { strain }\end{array}$ & Diarrhoea & Dysentery & $\begin{array}{c}\text { White } \\
\text { scour }\end{array}$ \\
\hline From 15 calves and cows & 31 & 13 & 8 & 10 \\
From 17 buffalo-calves and buffaloes & 39 & 21 & 8 & 10 \\
From 38 kids and goats & 83 & 69 & 14 & - \\
\hline Total: & 153 & 103 & 30 & 20 \\
\hline
\end{tabular}

Out of 20 carbohydrates, eight, namely, arabinose, dextrose, laevulose, galactose, trehalose and mannitol, were utilized by all the strains, and mucin and glycogen were utilized by none. Other biochemical fermentation reactions of the strains are given in Tables 2 and 3.

On the basis of results obtained with six selected substrates, the 153 strains could be classified into 28 biotypes (Table 4). Biotypes I, V, VI, XI, XVIII, and XX appear to be more common than the others. They accounted for nearly $60 \%$ of the total strains (Table 5). Biotype XX (negative for dulcitol, salicin, and starch) seems to be predominant in buffaloes and buffalocalves; type VI (negative for starch) in cows and calves, and in goats and kids. Type VI was common in diarrhoea and dysentery cases, and type XI (negative for salicin and starch) in white scour (Table 6).

Out of the 153 strains of Escherichia coli only 137 could be typed serologically. It can be seen from Table 7 that 65 strains (47.4\%), out of 137, belonged 
Table 2. Proportion of strains of $E$. coli (out of 153) producing acid and gas from 12 carbohydrates.

\begin{tabular}{|c|c|c|c|c|}
\hline \multirow{2}{*}{ Carbohydrates } & \multicolumn{2}{|c|}{ Number positive } & \multicolumn{2}{|c|}{$\begin{array}{c}\text { Positive } \\
(\%)\end{array}$} \\
\hline & A G & $\mathrm{A}$ & A G & $\mathrm{A}$ \\
\hline Sorbitol & 150 & 3 & 98.0 & 1.9 \\
\hline Lactose & 147 & 5 & 96.1 & 3.2 \\
\hline Maltose & 144 & 7 & 94.1 & 4.5 \\
\hline Xylose & 142 & 9 & 92.8 & 5.5 \\
\hline Rhamnose & 117 & 19 & 76.4 & 12.4 \\
\hline Sucrose & 76 & 39 & 49.7 & 25.4 \\
\hline Dulcitol & 108 & 6 & 70.5 & 3.8 \\
\hline Raffinose & 84 & 25 & 54.9 & 16.3 \\
\hline Salicin & 76 & 14 & 49.7 & 9.2 \\
\hline Starch & 2 & 32 & 1.3 & 20.9 \\
\hline Dextrin & 11 & 3 & 7.2 & 1.9 \\
\hline Adonitol & 6 & 0 & 3.9 & 0.0 \\
\hline
\end{tabular}

$A=$ acid $; A G=$ acid and gas.

Table 3. Biochemical characters of 153 strains of E. coli.

\begin{tabular}{l|c|c}
\hline \multicolumn{1}{c|}{ Test } & No. of strains positive & $\begin{array}{c}\text { Positive } \\
(\%)\end{array}$ \\
\hline Arginine dihydrolase & $34^{*}$ & 22.2 \\
Lysine decarboxylase & $32^{* *}$ & 20.9 \\
Ornithine decarboxylase & $100^{*}$ & 65.3 \\
Sodium mucate & $19^{* *}$ & 12.4 \\
& $82^{*}$ & 53.5 \\
Motility & $32^{* *}$ & 20.9 \\
\hline
\end{tabular}

$*$ positive in one day; ** positive in 2-3 days.

to seven human pathogenic ' $\mathrm{O}$ ' groups to which belong serotypes known to be associated commonly with enteritis of humans. The most commonly occurring human ' $\mathrm{O}$ ' groups are $\mathrm{O} 26, \mathrm{O} 119$, and $\mathrm{O} 125$. The proportion of human pathogenic ' $\mathrm{O}$ ' groups, isolated from cows and calves was the highest, followed by buffaloes and buffalo calves, and least in goats and kids (Table 8). Group O26 predominated in goats and kids, O125 in buffaloes and buffalo calves, and $\mathrm{O} 119$ in cows and calves. 
Table 4. Differentiation of 153 strains of $E$. coli into 28 biotypes based on their biochemical reactions towards rhamnose, dulcitol, sucrose, salicin, raffinose and starch.

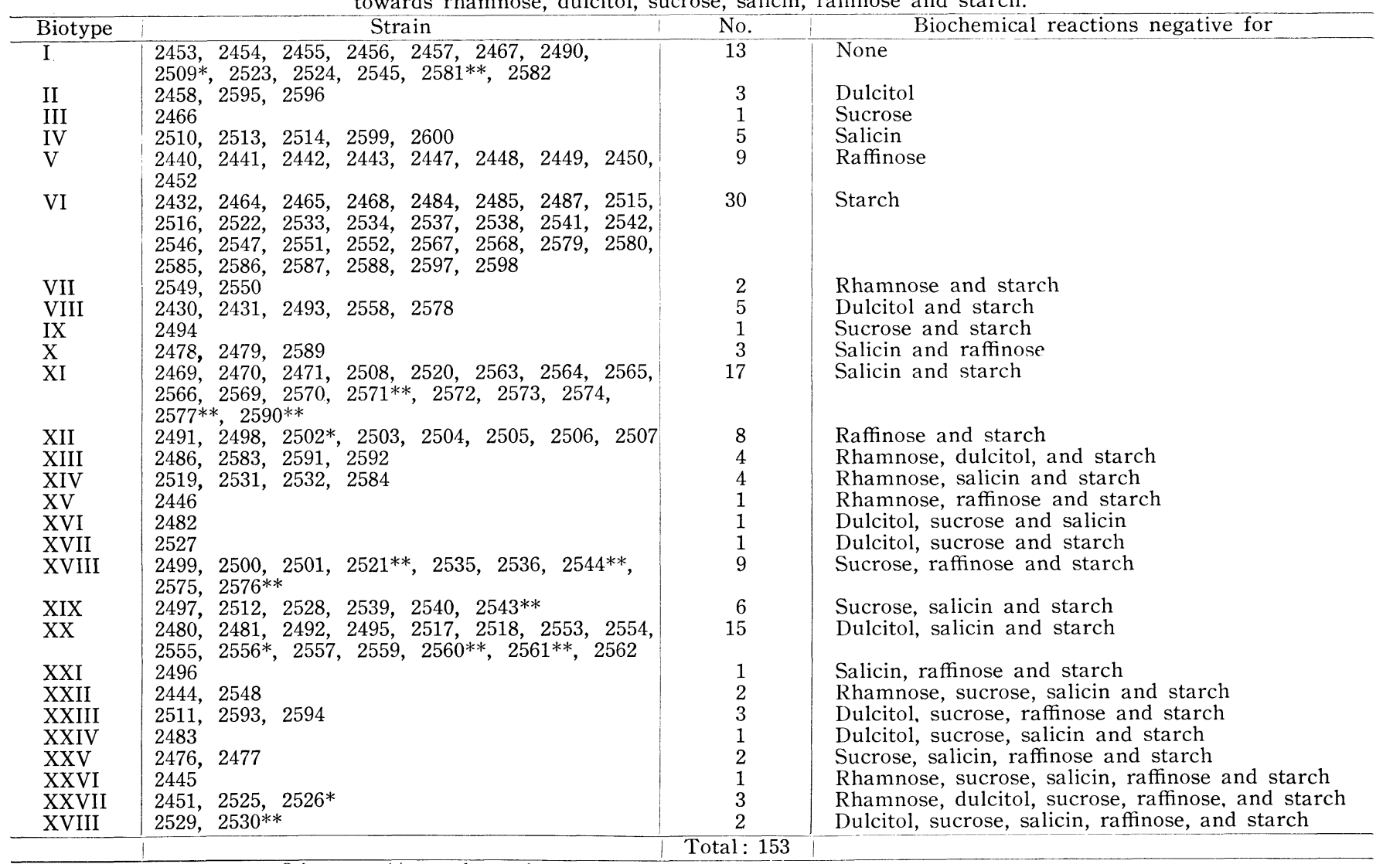

* negative in $1-147^{\prime} \mathrm{O}$ ' sera, ** rough strains, 
Table 5. Frequency of occurrence of the common E. coli biotypes among 153 strains in diseased animals.

\begin{tabular}{|c|c|c|c|c|c|c|c|c|c|}
\hline \multirow{2}{*}{ Animals } & \multirow{2}{*}{$\begin{array}{l}\text { Total } \\
\text { No. of } \\
\text { strains }\end{array}$} & \multicolumn{8}{|c|}{ Biotypes } \\
\hline & & I & $\mathrm{V}$ & VI & $\mathrm{XI}$ & XVIII & $\mathrm{XX}$ & Total & $\%$ \\
\hline Buffaloes and buffalo-calves & 39 & 2 & 5 & 1 & 2 & 0 & 8 & 18 & 46.1 \\
\hline Cows and calves & 31 & 2 & 4 & 10 & 5 & 2 & 2 & 25 & 80.6 \\
\hline Goats and kids & 83 & 9 & 0 & 19 & 10 & 7 & 5 & 50 & 60.2 \\
\hline Total & 153 & 13 & 9 & 30 & 17 & 9 & 15 & 93 & 60.75 \\
\hline
\end{tabular}

Table 6. Association of the common biotypes with forms of disease in animals.

\begin{tabular}{|c|c|c|c|c|c|c|c|c|c|}
\hline \multirow{2}{*}{ Diseases } & \multirow{2}{*}{$\begin{array}{l}\text { No. of } \\
\text { strains }\end{array}$} & \multicolumn{6}{|c|}{ Biotypes } & \multirow{2}{*}{ Total } & \multirow{2}{*}{$\%$} \\
\hline & & I & $\mathrm{V}$ & VI & XI & XVIII & $\mathrm{XX}$ & & \\
\hline Diarrhoea & 103 & 13 & 3 & 21 & 11 & 4 & 10 & 62 & 60.1 \\
\hline Dysentery & 30 & 0 & 6 & 7 & 0 & 3 & 3 & 19 & 63.3 \\
\hline White scour & 20 & 0 & 0 & 2 & 6 & 2 & 2 & 12 & 60.0 \\
\hline Total & 153 & 13 & 9 & 30 & 17 & 9 & 15 & 93 & 60.75 \\
\hline
\end{tabular}

Table 7. Occurrence in the diseased animals of ' $O$ ' groups commonly associated with human enteritis.

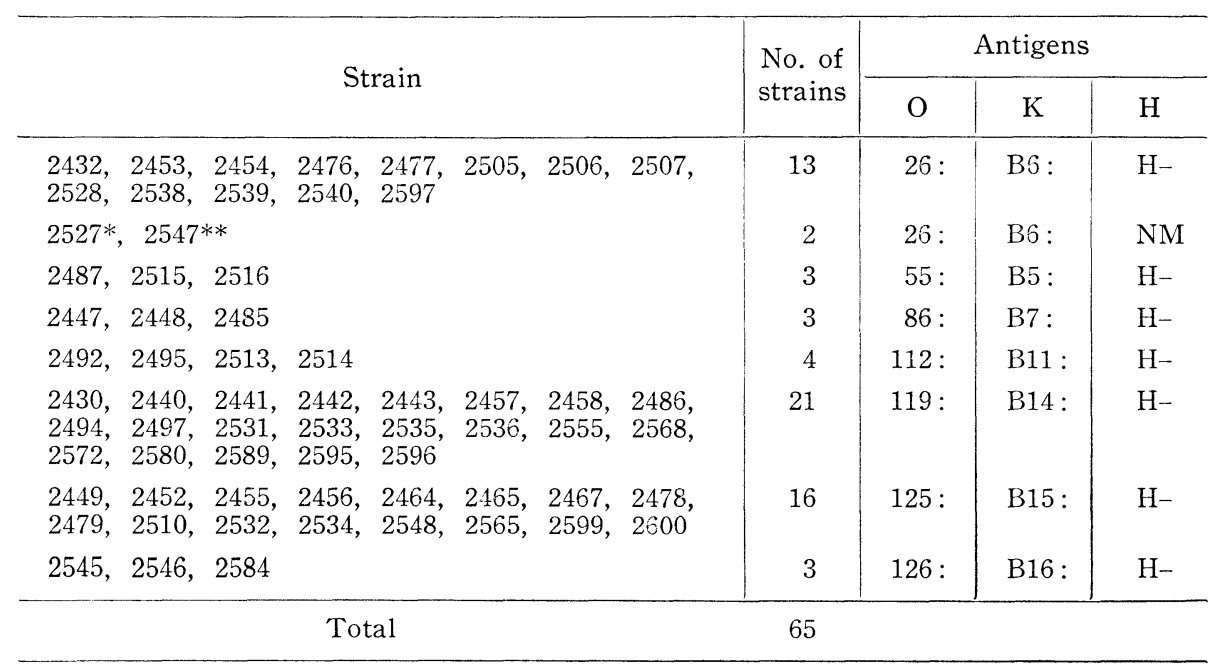

* 2527 (calf); ** 2547 (goat); $\mathrm{H}-=$ unknown; $\mathrm{NM}=$ non-motile. 
Table 8. Distribution of 38 ' $\mathrm{O}$ ' groups (137 strains) of $E$. coli isolated from diseased animals.

\begin{tabular}{|c|c|c|c|}
\hline Animals & $\begin{array}{l}\text { No. of } \\
\text { strains }\end{array}$ & ' $\mathrm{O}$ ' groups & $\begin{array}{l}\text { Proportion } \\
\text { of human } \\
\text { 'O' groups }\end{array}$ \\
\hline Goats and kids & 73 & $\begin{array}{l}\text { OX1, OX } 3, \text { OX } 6,3,6,9,10, \\
21,26,37,49,55,58,75,88, \\
94,102,103,110,119,125, \\
\mathbf{1 2 6}, 138,146(=24)\end{array}$ & $4: 24$ \\
\hline $\begin{array}{l}\text { Buffaloes and } \\
\text { buffalo-calves }\end{array}$ & 36 & $\begin{array}{l}9,49,61,76,83,86,88,101, \\
102,103,112,119,123,125, \\
141,147(=16)\end{array}$ & $4: 16$ \\
\hline Cows and calves & 28 & $\begin{array}{l}26, \quad 45,49, \mathbf{5 5}, \mathbf{8 6}, 91,108, \\
117, \mathbf{1 1 9}, \mathbf{1 2 5}, 134,140(=13)\end{array}$ & $5: 13$ \\
\hline
\end{tabular}

NB: The $\mathrm{O}$ antigen types, OX1, OX3, OX6, are provisional; those printed bold indicate human ' $\mathrm{O}$ ' groups.

Table 9. Biotypes of frequently occurring human enteropathogenic E. coli ' $\mathrm{O}$ ' groups isolated from diseased animals.

\begin{tabular}{|c|c|c|c|}
\hline $\begin{array}{l}\text { Frequently } \\
\text { occurring } \\
\text { 'O' groups }\end{array}$ & Serotypes & $\begin{array}{l}\text { No. of } \\
\text { strains }\end{array}$ & Biotypes \\
\hline $\mathrm{O} 26$ & $\begin{array}{l}\mathrm{O} 26: \mathrm{B} 6: \mathrm{H}- \\
\mathrm{O} 26: \mathrm{B} 6: \mathrm{NM}\end{array}$ & $\begin{array}{r}13 \\
2\end{array}$ & $\begin{array}{l}\text { I, VI, XII, XIX, XXV. } \\
\text { VI, XVII. }\end{array}$ \\
\hline $\mathrm{O} 119$ & $\mathrm{O} 119: \mathrm{B} 14: \mathrm{H}-$ & 21 & $\begin{array}{l}\text { I, II, V, VI, VII, VIII, IX, X, XI, } \\
\text { XIII, XIV, XVIII, XIX. }\end{array}$ \\
\hline $\mathrm{O} 125$ & $\mathrm{O} 125: \mathrm{B} 15: \mathrm{H}-$ & 16 & I, IV, V, VI, VII, X, XIV, XXII. \\
\hline
\end{tabular}

$\mathrm{H}-=$ flagellar antigen not known; $\mathrm{NM}=$ non-motile.

Strains differed serologically within a biotype and vice versa. For instance, thirty strains of the biotype VI (Table 4) belonged to at least seven human ' $\mathrm{O}$ ' groups (Table 7). Twenty-one strains, belonging to ' $\mathrm{O}$ ' antigen group 119, were distributed into 13 biotypes (I, II, V, VI, VII, VIII, IX, X, XI, XIII, XIV, XVIII, and XIX) (Table 9).

Apart from the seven human ' $O$ ' groups, 31 ' $O$ ' groups to which belong serotypes that are not known to be commonly associated with neonatal diarrhoea and gastroenteritis of humans were identified. They accounted for 72 strains $(52.6 \%)$ out of 153 studied (Table 10).

\section{DISCUSSION}

Detection of gastrointestinal diseases caused by pathogenic E. coli common to man and animals (zoonoses) has not received the attention of workers in India it deserves. This is because in most instances attempts at diagnosis 
Table 10. ' $O$ ' groups* of $E$. coli isolated from the diseased animals, not known to be commonly associated with human enteritis.

\begin{tabular}{|c|c|c|c|}
\hline No. of strains & Serotypes & No. of strains & Serotypes \\
\hline 2496 & $\mathrm{OX} 1: \mathrm{K}-: \mathrm{H} 16$ & 2466 & O88 : K- : H12 \\
\hline 2498 & $\mathrm{O} 3: \mathrm{K}-: \mathrm{H} 8$ & 2573,2574 & $\mathrm{O} 88: \mathrm{K}-\mathrm{H}$ ? \\
\hline 2512 & $\mathrm{OX} 3: \mathrm{K}-: \mathrm{H} ?$ & $2585,2586,2587,2588$ & O91 : K- : H14 \\
\hline 2591,2592 & $\mathrm{OX} 3: \mathrm{K}-: \mathrm{NM}$ & 2562 & O98 : K- : NM \\
\hline $2469,2470,2471$ & $\mathrm{OX} 6: \mathrm{K}-: \mathrm{H} 21$ & 2525 & O101 : K- : NM \\
\hline $\begin{array}{l}2499,2500,2501 \\
2582\end{array}$ & $\begin{array}{l}\mathrm{O} 6: \mathrm{K}-: \mathrm{H} 12 \\
\mathrm{O} 6: \mathrm{K}-: \mathrm{H} 9\end{array}$ & $\begin{array}{l}2563,2564,2593,2594 \\
2446\end{array}$ & $\begin{array}{l}\mathrm{O} 102: \mathrm{K}-: \mathrm{H} ? \\
\mathrm{O} 103: \mathrm{K}-: \mathrm{H} 8\end{array}$ \\
\hline 2598 & $\mathrm{O} 6: \mathrm{K}-\mathrm{:H} 21$ & $2517,2518,2541,2542$ & $\mathrm{O} 103: \mathrm{K}-\mathrm{:} \mathrm{H} 21$ \\
\hline $2451,2503,2504$ & $\mathrm{O} 9: \mathrm{K}(\mathrm{A}): \mathrm{NM}$ & 2578 & O103 : K- : H? \\
\hline 2529 & $\mathrm{O} 9: \mathrm{K}-: \mathrm{H} 10$ & 2566 & $\mathrm{O} 108: \mathrm{K}-\mathrm{:H} 7$ \\
\hline 2508 & $\mathrm{O} 10: \mathrm{K}-: \mathrm{H} ?$ & 2557,2558 & $(\mathrm{O} 110): \mathrm{K}-: \mathrm{H} 34$ \\
\hline $2549,2550,2551$ & $\mathrm{O} 21: \mathrm{K}-: \mathrm{H} 12$ & 2431 & $(\mathrm{O} 117): \mathrm{K}-: \mathrm{H} 47$ \\
\hline 2490,2491 & $\mathrm{O} 37: \mathrm{K}-: \mathrm{H} 8$ & $2553,2554,2559$ & $\mathrm{O} 123: \mathrm{K}-\mathrm{NM}$ \\
\hline 2575 & $\mathrm{O} 45: \mathrm{K}-: \mathrm{H} 8$ & 2484 & $(134): \mathrm{K}-: \mathrm{H} 21$ \\
\hline $2450,2569,2570$ & $\mathrm{O} 49: \mathrm{K}-\mathrm{:H} 12$ & 2511,2522 & $\mathrm{O} 138: \mathrm{K} 81: \mathrm{H} 48$ \\
\hline 2579,2583 & $\mathrm{O} 49: \mathrm{K}-: \mathrm{H} ?$ & 2253,2524 & $\mathrm{O} 140: \mathrm{K}-: \mathrm{H} 16$ \\
\hline $2519, \quad 2520$ & O58 : K- : H16 & 2493 & $(\mathrm{O} 141): \mathrm{K}: \mathrm{H} 48$ \\
\hline 2444 & $\mathrm{O} 61: \mathrm{K}-: \mathrm{H} 8$ & 2552 & O146- : K- : H? \\
\hline 2567 & $\mathrm{O} 75: \mathrm{K}-\mathrm{:} \mathrm{H} 10$ & 2445 & $\mathrm{O} 147: \mathrm{K}-\mathrm{:} \mathrm{H}$ ? \\
\hline $2480,2481,2482,2483$ & O76 : K- : H21 & & \\
\hline 2468 & $\mathrm{O} 83: \mathrm{K}-\mathrm{:H} 16$ & & \\
\hline
\end{tabular}

Total number of strains $=72 ; *$ No. of ' $\mathrm{O}$ ' groups $=31$;

? indicates negative in $\mathrm{H}$ sera; $\mathrm{O}$ antigen types in paranthesis indicate low titres.

and characterization of bacteria have ended with the identification of specific ' $\mathrm{O}$ ' group antigens known to be associated with human diarrhoeal infection. While this may serve the initial purpose, namely, of suggesting possible occurrence of cases of zoonoses, they need to be confirmed by analysis of flagellar antigens of the bacteria wherever possible. This at any rate was the view until a few years ago (5). Additionally, according to current knowledge, it would seem that identification and knowledge of specific chromosomal or extra-chromosomal biochemical markers (e.g., sugar reactions, drug resistance, phage sensitivity) of the isolated organisms may materially contribute to refinements of the existing technique of tracking source and origin of zoonoses $(33,34)$.

Accordingly, as a first step, biochemical characters of the 137 serologically identified strains of $E$. coli, locally isolated from cases of gastroenteritis of animals, were studied. Among these $65(42 \%)$ strains belonged to seven of 
12 ' $\mathrm{O}$ ' antigen groups to which belong serotypes that are commonly associated with human cases of gastroenteritis (27). Only one human pathogenic serotype $(\mathrm{O} 26: \mathrm{B} 6: \mathrm{NM})$ consisting of two strains was completely identified in faeces of calf and goat. If the knowledge of $\mathrm{H}$ antigens of all the 65 strains were available, perhaps a larger number of 'human' pathogenic serotypes could have been identified. It was of interest to note that of the seven human ' $\mathrm{O}$ ' antigen groups detected, only three, namely, O26, O119, and O125, predominated, accounting for as many as 52 of the 65 strains.

Apart from these seven human ' $\mathrm{O}$ ' groups, 31 other ' $\mathrm{O}$ ' groups, comprising 72 strains $(52.5 \%)$, were identified (Table 10 ). This gives in incidence ratio of one human 'pathogenic' to about four 'non-human' pathogenic ' $\mathrm{O}$ ' antigenic groups (Tables 7 and 10). EwING (5) observed in the course of a similar survey and study of 139 cultures of Escherichia coli from animal sources that belonged to 12 common human pathogenic ' $\mathrm{O}$ ' antigen groups, only $38(27.3 \%)$ were serotypes that are known to occur in association with diarrhoeal diseases in infants suggesting that majority of the cultures from animal sources studied by him were serotypes not known to be commonly associated with diarrhoea in human or about which there is very little information regarding such an association.

It was of interest to note that in our studies human ' $O$ ' group 86 was absent (Table 8 ) in goats and kids, and $\mathrm{O} 126$ from buffaloes and buffalo calves. In addition, several ' $\mathrm{O}$ ' antigen groups that occurred in buffaloes were not present in cows, and vice versa, even though about the same number of cultures were examined from each of the two species of animals. There is, therefore, a suggestion in these findings, that certain pathogenic ' $O$ ' groups may be closely associated with particular forms of the disease or the species of animals that suffer from it. Greater proportion of human ' $\mathrm{O}$ ' groups was obtained from cows and calves than from other species.

In quest of biotypes within a serotype, most workers seem to have taken into consideration the ability (or inability) of $E$. coli strains to ferment one or more substrates (notably carbohydrates). There is no general agreement or unanimity in the choice as to the minimum number, or types of substrates, that should be used for tests to identify biotypes of $E$. coli within a serotype. For instance, only sucrose, sorbose, and salicin were employed by MANSSON (16); sucrose, maltose, dulcitol, salicin, rhamnose, and adonitol by WRIGHT and VillanueVA (19); saccharose and salicin by SHIRLAW (22); sorbitol by RAPPAPORT and HENIG (15); sorbitol, dulcitol, salicin, and adonitol by KAUFFMANN and $\phi$ RSKOV (35); adonitol, dulcitol, inositol, rhamnose, salicin, saccharose, and xylose by KAUFFMANN and PERCH (1); and only sucrose by CHARTER and TAYLOR (17).

In the present study, in order to facilitate detection of maximum number of biotypes by the use of a minimum number of fermentation tests, only those substrates were considered suitable for inclusion in such tests which, on examination, were found to give variable reactions (Table 2), i.e., be de- 
graded (acid and gas production) by at least 10\% but not more than $90 \%$ of the strains. Such substrates were rhamnose, raffinose, salicin, dulcitol, sucrose and starch. By use of the above battery of tests it became possible to detect 28 different biochemical types or biotypes from among the 137 strains, classified into 38 ' $\mathrm{O}$ ' groups. More than one biotype could be detected within a single serotype. Also, within a single biotype (biotype VI) all the seven human enteropathogenic ' $\mathrm{O}$ ' antigen groups (O26, O55, O86, O112, O119, O125, and O126) were represented. It may be noted that, whereas nearly all (30 out of 32) starch-splitting strains were pathogenic (known to be associated with gastroenteritis of man or animals), all pathogenic strains were not starch splitting.

Biotypes of $E$. coli which predominated are: I (no substrates degraded). $\mathrm{V}$ (negative for raffinose), VI (negative for starch), XI (negative for salicin and starch), XVIII (negative for sucrose, raffinose, and starch), and XX (negative for salicin, sucrose, and starch). These biotypes accounted for nearly $60 \%$ of the 153 strains. Biotype VI predominated in cows and calves, but $\mathrm{XX}$ in buffaloes and their calves, even though almost the same number of strains were examined in two species of animals. Biotype VI also predominated in goats and kids.

Our sincere thanks are due to Dr. B.N. Singh, Deputy Director, Central Drug Research Institute, Lucknow, for his constructive criticism and keen interest in this work. Our thanks are also due to Dr. J.B. Shrivastav, Ex-Director and Dr. A.K. Thomas, Director, National Reference Centre for Salmonella and Escherichia, Central Research Institute, Kasauli, Punjab, for providing facilities to one of us (J.N.S. Yadava) for serological typing of E. coli strains, and to Dr. P. Von Magnus, Director International Escherichia and Salmonella Centre, Statens Serum Institute, Copenhagen, Denmark, for serotyping of some of the E. coli strains. The sincere help of Shri Sudhir Madhwar, Junior Laboratory Assistant, is acknowledged. The financial assistance of I.C.A.R. is also acknowledged with thanks.

\section{REFERENCES}

1) F. Kauffmann and B. Perch, Acta Pathol. Microbiol. Scand., 25, 608 (1948).

2) F. $\phi$ Rskov, Acta Pathol. Microbiol. Scand., 29, 373 (1951).

3) S.M.H. Bokari and F. $\phi$ Rskov, Acta Pathol. Microbiol. Scand., 30, 87 (1952).

4) P.J. GlantZ, Cornell Vet., 50, 9 (1960).

5) W.H. Ewing, J. Infect. Dis., 110, 114 (1962).

6) W.H. Ewing, B.R. Davis and T.S. Montague, Communicable Disease Centre, U.S. Dept. of Health Education and Welfare (1963), p. 38.

7) W.H. Ewing and B.R. DAvis, CDC Publication, Communicable Disease Centre, Atlanta, Georgia (1961 a).

8) A. DAM, Vet. Bull., 33, 609 (1963).

9) R. Lovell, Vet. Rev. Annot., 1, 1 (1955).

10) P.C. Wood, J. Pathol. Bact., 70, 179 (1955).

11) P.R. EdWards and W.H. EwING, Cornell Vet. 44, 50 (1954). 
12) T.A. Rees, J. Cemp. Pathol.. 68, 388 and 399 (1958).

13) R.E. Charter, J. Pathol. Bacteriol., 72, 33 (1956).

14) F. Kauffmann and A. Dupont, Acta Pathol., Microbiol. Scand., 27, 552 (1950).

15) F. Rappaport and E. Henig, J. Clin. Pathol., 5, 361 (1952).

16) I. Mansson, Acta Vet. Scand., 3, 65 and 69 (1962).

17) R.E. Charter and J. TAylor, J. Pathol. Bacteriol., 64, 729 (1952).

18) J. Wright, Brit. Med. J., 2, 460 (1950).

19) J. Wright and R. Villanueva, J. Hyg. Camb., 51, 39 (1953).

20) I. Cernea, C. Draghici, S. Bangau and I. Butura, Lucr. Inst. Pat. Igiena, anim. Bucuresti, 12, 97 (1963).

21) G. Wramby (1948), In Identification of Enterobacteriaceae ed. P.R. Edwards and W.H. Ewing, 2nd Ed., Burgess Publishing Company, Minneapolis (1962), p. 83.

22) J.F. Shirlaw, Brit. Vet. J., 116, 69 (1960).

23) M. GitTer and M.K. Lloyd, Brit. Vet. J., 113, 212 (1957).

24) P.J. Glantz and H.W. Dunne, Science, 121, 902 (1955).

25) E.G. Harry and L.G. Chubb, J. Comp. Pathol., 74, 180 (1964).

26) M.L. Cooper, E.W. Walters and H.M. Keller, Ann. N.Y. Acad. Sci., 66, 78 (1956).

27) P.R. Edwards and W.H. EwIng, In Identification of Enterobacteriaceae. 2nd Ed., Burgess Publishing Company. Minneapolis (1962), p. 240.

28) R. Cruickshank, Medical Microbiology. 11th Ed. The English Language Book Society and E. and S. Livingstone Ltd., Great Britain (1965), p. 827.

29) P.H. Clarke, J. Gen. Microbiol., 8, 397 (1953).

30) W.B. Christensen, J. Bacteriol., 52, 461 (1946).

31) S. Falkow, Am. J. Clin. Pathol., 29, 598 (1958).

32) P.R. Edwards and M.A. Fife, Appl. Microbiol., 4, 46 (1956).

33) E.S. Anderson, Brit. Med. J., 2, 1289 (1965).

34) T. Watanabe and T. Fukasawa, J. Bacteriol., 81, 669 (1961).

35) F. Kauffmann and F. $\phi$ RSKov, Die Bakteriologie der Escherichia coli Enteritis. In Saüglings-Enteritis ed. by Adam. thieme Stuttgart (1956). 